International Research Journal of Management, IT \& Social Sciences
Available online at https://sloap.org/journals/index.php/irjmis/
Vol. 7 No. 6, November 2020, pages: 175-183
$\begin{aligned} & \text { ISSN: 2395-7492 } \\ & \text { https://doi.org/10.21744/irjmis.v7n6.1035 }\end{aligned}$

\title{
The Belief on the Law of Karma Moderates the Effect of Idealism and Professional Commitment on the Ethical Decisions of Tax Consultants
}

\author{
Ni Made Vinayanthi ${ }^{a}$ \\ Made Gede Wirakusuma ${ }^{b}$ \\ Herkulanus Bambang Suprasto $^{c}$ \\ I G A M Asri Dwija Putri ${ }^{\mathrm{d}}$
}

Article history:

Submitted: 18 September 2020

Revised: 09 October 2020

Accepted: 27 November 2020

\section{Keywords:}

ethical decision;

idealism;

karma law;

professional commitment;

wider community;

\begin{abstract}
An ethical decision is a decision that is both legally and morally that can be accepted by the wider community. The importance of ethical decisions is taken in solving problems experienced effectively so that decisions taken do not violate applicable norms and can be accepted by the wider community. The purpose of this study is to find out and obtain empirical evidence about the role of belief in the law of karma in moderating the influence of idealism and professional commitment to the ethical decisions of tax consultants. The population in this study are all registered tax consultants in the Province of Bali. This research analysis technique uses Moderate Regression Analysis (MRA). Based on the results of the analysis it was found that idealism has a positive effect on the ethical decisions of tax consultants. Professional commitment has a positive effect on the ethical decisions of tax consultants. Belief in the law of karma reinforces the influence of idealism on the ethical decisions of tax consultants. Belief in the law of karma reinforces the influence of professional commitment on the ethical decisions of tax consultants.
\end{abstract}

International research journal of management, IT and social sciences (C) 2020. This is an open access article under the CC BY-NC-ND license (https://creativecommons.org/licenses/by-nc-nd/4.0/).

\section{Corresponding author:}

Ni Made Vinayanthi,

Faculty of Economy and Business, Udayana University, Denpasar, Indonesia.

Email address: made.vinayanthi@gmail.com

${ }^{a}$ Faculty of Economy and Business, Udayana University, Denpasar, Indonesia

${ }^{b}$ Faculty of Economy and Business, Udayana University, Denpasar, Indonesia

Faculty of Economy and Business, Udayana University, Denpasar, Indonesia

Faculty of Economy and Business, Udayana University, Denpasar, Indonesia 


\section{Introduction}

Ethical decisions are essentially based on the ethical theory which shows the normative judgments about a person's behavior are correct or have been according to what should be done (Brooks \& Dunn, 2011). Ethical decisions are decisions that are both legally and morally acceptable to society (Trevino, 1986). Kohlberg's theory of moral development (1969) also states that individual moral reasoning is the basis of ethical behavior, including in decision making. The importance of ethical decisions is taken to solving the problems effectively so that the taken decisions do not violate applicable norms and can be accepted by society.

Tax consultants have an ethical code that functions to maintain professionalism, integrity, and independence in performing their duties. The basic principles of professional ethics of a tax consultant are the moral principles that will serve as the guidelines in thinking, behaving, and acting to make ethical decisions. This code of conduct serves as a guideline for tax consultants to comply with applicable tax laws and regulations (KEPKP, 2015).

However, on the other hand, the tax consultant's expertise can be misused by the taxpayer (Dewi et al., 2019). What is meant is the possibility of a tax consultant will infringe the prohibitions set out in The Ethics Code of the Indonesian Tax Consultant Association regarding receiving requests from taxpayers or other parties to carry out fraud or actions that are contrary to tax regulations. Several important matters related to tax consultants are regulated in Articles 28 and 29 of the Minister of Finance Regulation No.111/PMK.03/2014 which provides very tight supervision for tax consultants. According to the issue, the ethic code also describes the existence of regulations that is related to supervision, examination, and sanctions for infringing the ethic code. If a tax consultant handles a taxpayer and in the end, the taxpayer experiences a dispute and even becomes a suspect in a tax crime, the tax consultant's operational permit will be frozen and even revoked.

There are two conflicts of interest (Dual Agency), namely in the relationship between the tax consultant and the client where the consultant must establish a good relationship with the client and also, on the other hand, the consultant must comply with applicable government regulations, thus causing the tax consultant to be faced with ethical dilemma conditions, which are always threatening the credibility and integrity of these professionals. Ethical dilemmas in a profession can be resolved by several factors, such as ethical orientation formed by self-idealism to maintain independence and self-integrity in making decisions (Forsyth, 1980; O’Higgins \& Kelleher, 2005). Idealism relates to activities that are based on ethical and moral values. All the professionals including tax consultants who have high idealism should be able to maintain their independence and integrity in making a decision that will always be guided by the morals and ethics of their profession as tax consultants, so they will not be easily influenced by the bribe and economic rewards or another reward that can drop credibility. and integrity as a practitioner in the field of taxation.

Another alternative that can be used to deal with ethical dilemmas is professional commitment. Larkin (1990), states that professional commitment is loyalty to the profession that is owned by the individual. Professional commitment refers to the strength of an individual's identification of his profession. Mowday et al. (1979), stated that individuals with high professional commitment have high trust and acceptance in professional goals, desire to do their best on behalf of the profession, and have a strong desire to maintain their existence in the profession and maintain the good name of their profession. Someone who is committed to their profession will be loyal to the interest of their profession.

The connection between idealism and commitment is on the ethical decision of tax consultants that can be described in the theory of planned behavior (TPB). TPB stated that the central factor of individual behavior is the behavior that has been influenced by some variables such as attitude, the subjective norm. and perceived behavioral control (Shaub et al., 1993). In making an ethical decision tax consultant's behavior can be influenced by the attitude that is reflected in the idealism of the tax consultant and by the subjective norms that are reflected in his professional commitment.

This study describes the perceived behavior control variable, namely individual beliefs about the existence of things that support or hinder their behavior and their perceptions about how strongly these things affect their behavior as reflected in the belief in the law of karma which can moderate the effect of idealism and professional commitment on the ethical decisions of tax consultants.

This belief in the Law of Karma was chosen as a moderating variable in this study because the way a person judges an action is ethical or unethical is inseparable from his or her beliefs (Hafizhah et al., 2016). The concept of karma has always been applied as a philosophy of practical action. According to this philosophy, karma is not just a spiritual law, but also a principle which demands good intentions. As a tax consultant who believes in the law of karma, he will act properly, manage thoughts and emotions to be able to make ethical decisions (Singhapakdi et al., 1996; Fraedrich \& Ferrell, 1992; Aksiana \& Sujana, 2019). Based on this explanation, the purpose of this study is to provide empirical 
evidence regarding the influence of idealism and professional commitment to the Tax Consultant's ethical decisions which are moderated by the belief in the law of karma.

Theory of Planned Behavior (TPB), put forward by Shaub et al. (1993). This theory states that the central factor of individual behavior is that the behavior is influenced by the individual's intention towards that particular behavior. The intention to behave is influenced by the variable attitude, subjective norms, and perceived behavioral control. This theory is based on the postulate theory which states that behavior is a function of information or beliefs that stand out explains the behavior.

The perspective of agency theory caused an asymmetrical relationship between owners and managers, to avoid this asymmetric relationship. Agency theory explains the relationship between management and owners, management as an agent is morally responsible for optimizing the profits of the owners (principal) and in return will get compensation following the contract. Blanthorne et al. (2014), stated that there is a dual agency problem in the relationship between tax consultants and clients. On the one hand, consultants must maintain good relationships with clients, but on the other hand, consultants must comply with tax regulations. This raises an ethical dilemma for tax consultants where they must make decisions that are contrary to the principles of their profession while the economic benefits provided are quite material and affect the continuation of the services.

The theory of development moral by Kohlberg (1976), states that logic and morality develop and holds that moral reasoning is the basis for ethical behavior. A tax consultant who has good moral development can make an ethical decision when they face situations that question his profession.

Self-idealism that a person has can maintain independence and self-integrity in making a decision (Forsyth, 1980; O'Higgins \& Kelleher, 2005). An idealist attitude is defined as being impartial and avoiding various interests. A tax consultant also needs to maintain his idealism so that he can make ethical decisions and can carry out his obligations as an extension of the government to increase taxpayers. Harmana et al. (2017); Yuliani (2011); and Metin (2011), found that idealism has a positive effect on ethical decision making. According to previous research, the hypothesis can be formulated:

H1: Idealism has a positive effect on the ethical decisions of tax consultants in Bali Province.

Professional commitment is loyalty to the profession that is owned by individuals (Larkin, 1990). Professional commitment is a positive attitude towards a profession to maintain the reputation of the profession. In particular, high professional commitment should encourage professionals to behave following the public interest and away from behavior that will harm or infringe on the profession (Aranaya \& Ferris, 1984). The research of Yuliani (2011), found that professional commitment has a positive effect on ethical decision making. According to the previous explanation the hypothesis can be formulated as:

H2: Professional commitment has a positive effect on the ethical decisions of tax consultants in Bali province.

An idealist attitude is defined as an attitude of being impartial and avoiding various interests. The law of karma also guides people who believe in the law of karma to believe that whatever is experienced in this life is the result of one's actions, not because of others. Handayani et al. (2017), explained that individuals who have faith in the law of karma thinking to a long-term orientation, and as result, they will behave more ethically in their lives. This is because the belief in the law of karma tends to encourage one's willingness to think well before deciding to do something. The higher the level of faith in the law of karma from the tax consultant, the greater the tax consultant can control his behavior and inhibit bad behavior by avoiding unethical actions, which in this case is related to decision making. Based on this framework, the following hypotheses can be formulated:

H3: Belief in the law of karma strengthens the influence of idealism on the ethical decisions of tax consultants in the Bali province

Professional commitment refers to the strength of an individual's identification with his profession. The law of karma as the basic teaching of self-control is the main teaching for improving human morals and ethics in social life. Handayani et al. (2017), explained that individuals who have faith in the law of karma will have confidence that all individual actions will not be separated from the right consequences in the future. If the higher the level of faith in the law of karma from the tax consultant, the greater the tax consultant can control his behavior and inhibit bad behavior by avoiding unethical actions which in this case are related to decision making. Based on this framework, the following hypotheses can be formulated:

H4: Belief in the law of karma strengthens the influence of professional commitment on the ethical decisions of tax consultants in Bali province

Vinayanthi, N. M. ., Wirakusuma, M. G. ., Suprasto, H. B. ., \& Putri, I. G. A. M. A. D. . (2020). The belief on the law of karma moderates the effect of idealism and professional commitment on the ethical decisions of tax consultants. International Research Journal of Management, IT and Social Sciences, 7(6), 175-183. https://doi.org/10.21744/irjmis.v7n6.1035 
Based on the description of the above hypothesis, the concept of this study can describe how the relationship between idealism and professional commitment to tax consultant's ethical decision making is moderated by the belief of the law of karma.

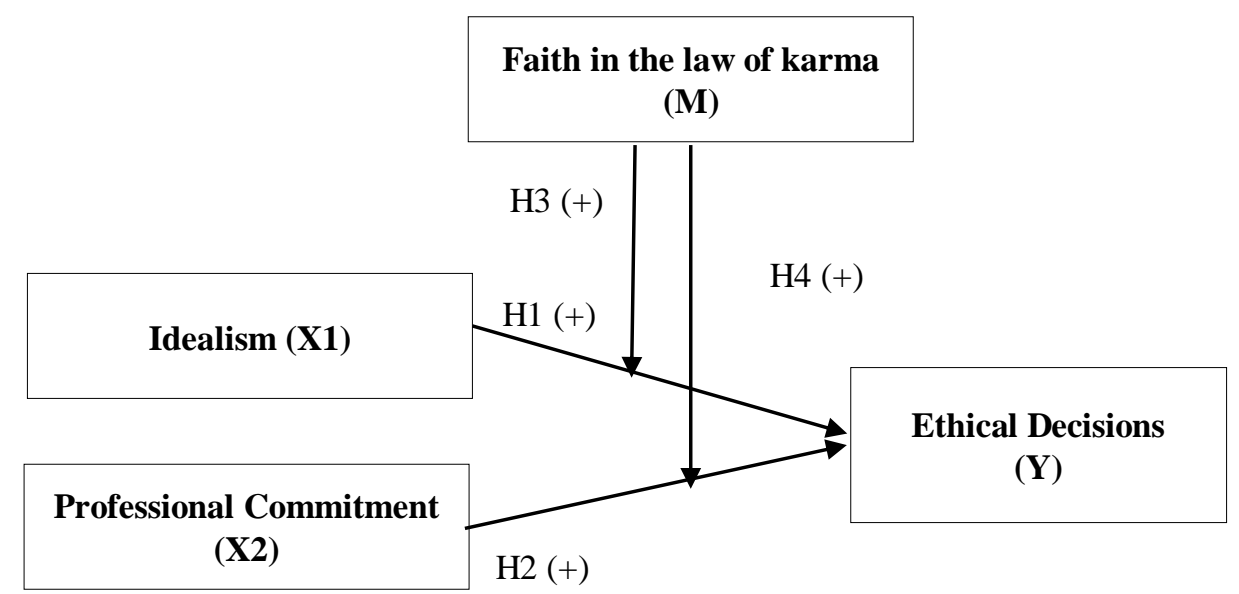

Figure 1. The research concept

\section{Materials and Methods}

This research was conducted in 2019 on a registered tax consultant in the Bali province as a representation of the Tax Consultants in Indonesia. The object of research in this study is the behavioral aspects related to the influence of idealism and professional commitment on tax consultant's ethical decision making moderated by the belief in the law of karma in registered tax consultants in Bali Province.

The population in this study is all registered tax consultants in the Bali province who have a license according to the IKPI Directory (2019), and who are still active. The unit of analysis in this research is the behavioral aspect of each tax consultant. The sampling method that has been used in this study is the nonprobability sampling method with saturated sampling techniques, this is the sampling technique when all the members of the population are used as samples (Sugiyono, 2013), to get a representative sample. So, the samples in this study are all the registered tax consultants in the Bali province who have licensed practice according to the IKPI Directory (2019) and are still active.

This study used a survey method with a questionnaire technique to collect the data. The independent variables in this study are idealism and professional commitment (Mela \& Zarefar, 2016; Lu et al., 2007). The dependent variable in this study is ethical decision making, and the moderating variable is the belief in the law of karma. The measurement of variables uses a four-point Likert scale to avoid the multi interpretable and central tendency effect.

The variable of ethical decision making was measured using four case scenarios which are a modification of the measurement of ethical decision making, with indicators of flexibility, compliance with regulations, the fulfillment of client interests, and sabotage of clients of fellow professionals (Yuliani, 2011). Measuring idealism by referring to something to be believed by individuals that do not violate moral values. Idealism was measured using the following indicators: Evaluation of actions, Tolerance, Physical and psychological actions, Assessment (Januarti, 2011). Professional commitment is measured using the following indicators: Awareness and volunteerism, Pride in the profession, Motivation, Sacrifice, Self-Development, Care for the profession (Januarti, 2011). The measurement dimensions used in this study are the cause-effect and consequence (Asri, 2018).

Interaction testing or it is often called Moderated Regression Analysis (MRA) is done to find out whether a variable included in the study is a moderating variable. The moderating variable is an independent variable that will strengthen or weaken the relationship between the independent variable and the dependent variable. This study used an interaction test with the following equation formula below:

$$
Y=\alpha+\beta_{1} X_{1}+\beta_{2} X_{2}+\beta_{3} M_{1}+\beta_{4} X_{1} * M_{1}+\beta_{5} X_{2} * M_{1}+\varepsilon
$$




\section{Results and Discussions}

The results of the instrument validity test for each statement item from each research variable had a correlation coefficient value that was more than 0.30, this means all the statement items on the research questionnaire could be declared valid. The results of the reliability test of each research variable had a Cronbach's alpha value of more than 0.70 so that the research variables could be declared reliable. The normality test in this study is seen based on the results of multiple regression tests and moderation regression, it is known that the coefficient value of the Statistical Test is 0.093 and 0.103 , respectively, with a significance level of 0.087 and 0.077 more than 0.05 . This means the data is normally distributed.

The multicollinearity test is seen based on the results of multiple linear regression tests, it can be seen that each research variable has a tolerance value of more than 0.10 and a VIF value of less than 10 . This means the regression model is free from multicollinearity symptoms. The heteroscedasticity test is determined based on the results of multiple linear regression tests and moderation regression can be seen that the significance value of each independent variable is more than 0.05 . This means the regression model is free from heteroscedasticity symptoms.

Table 1

Results of multiple linear regression analysis

\begin{tabular}{|c|c|c|c|c|c|}
\hline \multirow[t]{2}{*}{ Model } & \multicolumn{2}{|c|}{$\begin{array}{c}\text { Unstandardized } \\
\text { Coefficient }\end{array}$} & \multirow{2}{*}{$\begin{array}{c}\begin{array}{c}\text { Standardized } \\
\text { Coefficient }\end{array} \\
\text { Beta } \\
\end{array}$} & \multirow[t]{2}{*}{$\mathrm{T}$} & \multirow[t]{2}{*}{ Sig. } \\
\hline & $\mathrm{B}$ & Std. Error & & & \\
\hline Constant & 1,091 & 0,624 & & 1,748 & 0,084 \\
\hline Idealism & 0,341 & 0,051 & 0,507 & 6,725 & 0,000 \\
\hline $\begin{array}{l}\text { Professional Commitment } \\
\mathrm{R}^{2}\end{array}$ & 0,215 & 0,038 & $\begin{array}{l}0,432 \\
0,788\end{array}$ & 5,731 & 0,000 \\
\hline $\begin{array}{l}\text { Adjusted }\left(\mathrm{R}^{2}\right) \\
\mathrm{F} \\
\text { Sig. F }\end{array}$ & & & $\begin{array}{c}0,784 \\
184,185 \\
0,000\end{array}$ & & \\
\hline
\end{tabular}

The regression equation generated from the multiple regression model in this study is:

$\mathrm{Y}=\mathrm{a}+\mathrm{b} 1 \mathrm{X} 1+\mathrm{b} 2 \mathrm{X} 2+\mathrm{e}$

$\mathrm{Y}=1.091+0.341 \mathrm{X} 1+0.215 \mathrm{X} 2+\mathrm{e}$

Based on Table 1, it is known that the calculated $\mathrm{F}$ coefficient value is 184.185 with a significance of 0.000 less than 0.05 . This means all independent variables, idealism, and professional commitment can explain the ethical decisions as to the dependent variable so that the model in this study is suitable to be used in conducting further analysis. The coefficient of determination can be seen from the adjusted R square value of 0.784 which means that $78.40 \%$ of variations in the ups and downs of changes in tax consultant ethical decisions are influenced by the independent variables of idealism and professional commitment, while the remaining $21.60 \%$ is influenced by other variables that are not explained in the model.

Based on Table 1, hypothesis 1 and hypothesis 2 can be tested with the following results: The first hypothesis aims to test the effect of idealism on the tax consultant's ethical decisions. The test results in Table 1 . indicate that the t-test coefficient is 6.725 with a significance level of 0.000 less than 0.05 . This means that idealism has a positive effect on the tax consultant's ethical decisions so that $\mathrm{H} 1$ is accepted. The higher the level of the idealism tax consultant has, the more ethical the decision will be made by the tax consultant. A tax consultant who can maintain his idealism will be able to make ethical decisions so that he can carry out his obligations as an extension of the government to increase taxpayer compliance (Armstrong, 2006; Comerio, 1984).

The second hypothesis testing aims to examine the effect of professional commitment on the tax consultant's ethical decisions. The test results in Table 1. indicate that the t-test coefficient is 5.731 with a significance level of 0.000 less than 0.05 . This means that professional commitment has a positive effect on the tax consultant's ethical decisions so that $\mathrm{H} 2$ is accepted. The higher the professional commitment a tax consultant has, the more ethical the decision will be made by the tax consultant. Tax consultants who always comply with applicable tax regulations will always try to make ethical decisions in helping clients to carry out their tax obligations.

Vinayanthi, N. M. ., Wirakusuma, M. G. ., Suprasto, H. B. ., \& Putri, I. G. A. M. A. D. . (2020). The belief on the law of karma moderates the effect of idealism and professional commitment on the ethical decisions of tax consultants. International Research Journal of Management, IT and Social Sciences, 7(6), 175-183. https://doi.org/10.21744/irjmis.v7n6.1035 
The research data was processed using Moderated Regression Analysis (MRA) and the results of data processing can be seen in Table 2.

Table 2

Moderated Regression Analysis (MRA)

\begin{tabular}{|c|c|c|c|c|c|}
\hline \multirow[b]{2}{*}{ ç } & \multicolumn{2}{|c|}{$\begin{array}{l}\text { Unstandardized } \\
\text { Coefficient }\end{array}$} & \multirow{2}{*}{$\begin{array}{c}\begin{array}{c}\text { Standardized } \\
\text { Coefficient }\end{array} \\
\text { Beta }\end{array}$} & \multirow{2}{*}{$\mathrm{T}$} & \multirow{2}{*}{ Sig. } \\
\hline & $\mathrm{B}$ & $\begin{array}{c}\text { Std. } \\
\text { Error }\end{array}$ & & & \\
\hline Constant & 0,017 & 0,298 & & 0,055 & 0,956 \\
\hline Idealism & $-0,011$ & 0,028 & $-0,053$ & $-0,404$ & 0,687 \\
\hline Professional Commitment & 0,019 & 0,021 & 0,119 & 0,913 & 0,363 \\
\hline $\begin{array}{l}\text { The Belief in Law of } \\
\text { Karma }\end{array}$ & $-0,020$ & 0,028 & $-0,107$ & $-0,697$ & 0,488 \\
\hline $\begin{array}{l}\text { The Interaction of Idealism } \\
\text { and Belief in the Law of } \\
\text { Karma }\end{array}$ & 0,403 & 0,130 & 0,306 & 3,097 & 0,003 \\
\hline $\begin{array}{l}\text { The Interaction of } \\
\text { Professional Commitment } \\
\text { and The Belief in the Law } \\
\text { of Karma }\end{array}$ & 0,562 & 0,111 & 0,494 & 5,077 & 0,000 \\
\hline $\mathrm{R}^{2}$ & & & 0,576 & & \\
\hline Adjusted $\left(\mathrm{R}^{2}\right)$ & & & 0,554 & & \\
\hline $\mathrm{F}$ & & & 26,051 & & \\
\hline Sig. F & & & 0,000 & & \\
\hline
\end{tabular}

Based on Table 2., a moderation regression equation can be formulated from this study, which is as follows:

$$
\begin{aligned}
& \mathrm{Y}=\alpha+\beta 1 \mathrm{X} 1+\beta 2 \mathrm{X} 2+\beta 3 \mathrm{X} 3+\beta 4 \mathrm{X} 1 \mathrm{X} 3+\beta 5 \mathrm{X} 2 \mathrm{X} 4+\mathrm{e} \\
& \mathrm{Y}=0.017-0.011 \mathrm{X} 1+0.019 \mathrm{X} 2-0.020 \mathrm{X} 3+0.403 \mathrm{X} 1 \mathrm{X} 3+0.562 \mathrm{X} 2 \mathrm{X} 4+\mathrm{e}
\end{aligned}
$$

Based on the results of the Moderated Regression Analysis (MRA) test, it can be explained related to the feasibility test of the model, the coefficient of determination, and hypothesis testing (t-test). Based on Table 2, it is known that the calculated $\mathrm{F}$ coefficient value is 26.051 with a significance of 0.000 less than 0.05 . This means all independent variables, namely idealism, professional commitment and the belief in the law of karma and all the interaction variables can explain ethical decisions as to the dependent variable so that the model in this study is suitable to be used in conducting further analysis. The adjusted $\mathrm{R}$ square value is 0.554 which means that $55.40 \%$ of variations of changes in tax consultant ethical decisions are influenced by the independent variables of idealism, professional commitment, the belief in the law of karma, interaction of idealism, and belief in the law of karma as well as the interaction of professional commitment and belief in the law of karma, while the remaining $44.60 \%$ is influenced by other variables that are not explained in this research model.

Based on Table 2, it can be discussed about testing hypothesis 3 and hypothesis 4, which are described as follows. The third hypothesis testing aims to test the law of karma in moderating the effect of idealism on the tax consultant's ethical decisions. The test results in Table 2. indicate that the t-test coefficient is 3.097 with a significance level of 0.003 less than 0.05 . This means that the belief in the law of karma influences idealism on the tax consultant's ethical decisions so that H3 is accepted. The higher the level of idealism that has been possessed by a tax consultant and having a high belief in the law of karma, the more ethical the decisions will be taken by the tax consultant. The fourth hypothesis testing aims to test the law of karma in moderating the effect of professional commitment on the tax consultant's ethical decisions. The test results in Table 2. indicate that the t-test coefficient is 5.077 with a significance level of 0.000 less than 0.05 . This means that belief in the law of karma influences the tax consultant's ethical decisions, so H4 is rejected. The higher the level of professional commitment a tax consultant has and a high level of belief in the law of karma, the more ethical the decision will be made by the tax consultant. 


\section{Conclusion}

Based on the formulation of the problem, research purpose, theory, hypothesis and the results of the tests carried out, the conclusions can be described as follows. 1) The more idealistic a tax consultant is, the more ethical the decision will be made by the tax consultant. 2) The more committed a tax consultant is to his profession, the more ethical the decision will be made by the tax consultant. 3) The more idealistic a tax consultant is and supported by having faith in the existence of karmic law, the more ethical the decision made by the tax consultant will be, and 4) The more committed a tax consultant is to his profession and supported by having confidence in the law of karma, then decisions made by the tax consultant will be more ethical.

Suggestions put forward in this study are based on the results and discussion obtained by the researcher, namely for tax consultants registered in the area of Bali province, to increase idealistic attitudes, especially regarding tolerance by prioritizing an attitude of prudence in doing work so it will not harm the other parties, and to increasing professional commitment tax consultants are expected will raise more concern to their profession by always working based on a professional code of ethics in making decisions to foster trust in the community.

Suggestions for further research, according to the adjusted R square value is only 55.4 percent and the remaining 44.6 percent is influenced by other variables outside the research model, this number is quite large, so it is advisable to add other variables both independent and moderating variables that might be able to influence these relationships, such as work stress variables, locus of control and emotional intelligence. Moreover, the next research could be used as an experimental design with any treatments to rise the internal validity.

\section{Conflict of interest statement}

The authors declared that they have no competing interests.

\section{Statement of authorship}

The authors have a responsibility for the conception and design of the study. The authors have approved the final article.

\section{Acknowledgments}

We are grateful to two anonymous reviewers for their valuable comments on the earlier version of this paper.

Vinayanthi, N. M. ., Wirakusuma, M. G. ., Suprasto, H. B. ., \& Putri, I. G. A. M. A. D. . (2020). The belief on the law of karma moderates the effect of idealism and professional commitment on the ethical decisions of tax consultants. International Research Journal of Management, IT and Social Sciences, 7(6), 175-183. https://doi.org/10.21744/irjmis.v7n6.1035 


\section{References}

Aksiana, I. B. W., \& Sujana, I. K. (2019). Effect of Risk Preference, Professional Domination, Information, and Professional Relationship on Ethical Decision Making of Tax Consultants. International research journal of management, IT and social sciences, 6(4), 174-179.

Aranya, N., \& Ferris, K. R. (1984). A reexamination of accountants' organizational-professional conflict. Accounting review, 1-15.

Armstrong, P. (2006). Ideology and the grammar of idealism: the Caterpillar controversy revisited. Critical Perspectives on Accounting, 17(5), 529-548.

Asri, I.A.T.Y. (2018). Keyakinan Pada Hukum Karma Memoderasi Pengaruh Sistem Perpajakan Pada Persepsi Penggelapan Pajak Wajib Pajak Orang Pribadi Di Seluruh Kantor Pelayanan Pajak Pratama Wilayah Bali. Tesis. Magister Akuntansi Fakultas Ekonomi dan Bisnis. Universitas Udayana.

Blanthorne, C., Burton, H. A., \& Fisher, D. (2014). The Aggressiveness of Tax Professional Reporting: Examining the Influence of Moral Reasoning 2 ' Data Availability: Contact authors. In Advances in Accounting Behavioral Research. Emerald Group Publishing Limited.

Brooks, L. J., \& Dunn, P. (2011). Business \& professional ethics. Nelson Education.

Comerio, M. C. (1984). Community design: Idealism and entrepreneurship. Journal of Architectural and Planning Research, 227-243. https://doi.org/10.1016/j.cpa.2005.07.001

Dewi, A. A. I. P., Sudarma, M., \& Baridwan, Z. (2019). Mengupas Bentuk Dilema Dari Sisi Konsultan Pajak. Jurnal Ilmiah Akuntansi dan Bisnis, 14(1), 132-141.

Forsyth, D. R. (1980). A taxonomy of ethical ideologies. Journal of Personality and Social psychology, 39(1), 175.

Fraedrich, J. P., \& Ferrell, O. C. (1992). The impact of perceived risk and moral philosophy type on ethical decision making in business organizations. Journal of Business Research, 24(4), 283-295. https://doi.org/10.1016/01482963(92)90035-A

Hafizhah, I., Basri, Y. M., \& Rusli, R. (2016). Pengaruh Etika Uang (Money Ethics) terhadap Kecurangan Pajak (Tax Evasion) dengan Religiusitas, Gender, dan Materialisme sebagai Variabel Moderasi (Studi pada Wp Op yang Melakukan Kegiatan USAha atau Pekerjaan Bebas di Pekanbaru) (Doctoral dissertation, Riau University).

Handayani, I. R. U., Ratnadi, N. M. D., \& Putri, I. A. D. (2017). Analisis Perbedaan Perilaku Etis Pelaku Akuntansi Dalam Etika Penyusunan Laporan Keuangan Satuan Kerja Perangkat Daerah Kabupaten Badung. E-Jurnal Ekonomi dan Bisnis Universitas Udayana.

Harmana, M. D., Wirakusuma, M. G., \& Wirama, D. G. (2017). Pengaruh idealisme, pengalaman, dan komitmen profesional pada pembuatan keputusan etis konsultan pajak terdaftar di wilayah bali-nusa tenggara. E-Jurnal Ekonomi dan Bisnis Universitas Udayana, 6, 3549-3578.

Januarti, I. (2011). Analisis Pengaruh Pengalaman Auditor, Komitmen Profesional, Orientasi Etis dan Nilai Etika Organisasi Terhadap Persepsi dan Pertimbangan Etis (Auditor Badan Pemeriksa Keuangan Indonesia). Paper Dipresentasikan pada Simposium Nasional Akuntansi XIV, Aceh.

Kohlberg, L. (1976). Moral stages and moralization. Moral development and behavior, 31-53.

Larkin, J. M. (1990). Does Gender Affect Auditor KAPs' Performance? The woman CPA.

Lu, K. Y., Chang, L. C., \& Wu, H. L. (2007). Relationships between professional commitment, job satisfaction, and work stress in public health nurses in Taiwan. Journal of Professional Nursing, 23(2), 110-116. https://doi.org/10.1016/j.profnurs.2006.06.005

Mela, N. F., \& Zarefar, A. (2016). The Relationship of professional commitment of auditing student and anticipatory socialization toward whistleblowing intention. Procedia-Social and Behavioral Sciences, 219, 507-512. https://doi.org/10.1016/j.sbspro.2016.05.027

Metin, U. Y. A. R. (2011). The ethical orientation and professional commitment: An empirical examination on Turkish accountants. African Journal of Business Management, 5(23), 10023-10037.

Mowday, R. T., Steers, R. M., \& Porter, L. W. (1979). The measurement of organizational commitment. Journal of vocational behavior, 14(2), 224-247. https://doi.org/10.1016/0001-8791(79)90072-1

O'Higgins, E., \& Kelleher, B. (2005). Comparative perspectives on the ethical orientations of human resources, marketing and finance functional managers. Journal of Business Ethics, 56(3), 275-288.

Shaub, M. K., Finn, D. W., \& Munter, P. (1993). The effects of auditors' ethical orientation on commitment and ethical sensitivity. Behavioral Research in Accounting, 5(1), 145-169.

Singhapakdi, A., Vitell, S. J., \& Kraft, K. L. (1996). Moral intensity and ethical decision-making of marketing professionals. Journal of Business research, 36(3), 245-255. https://doi.org/10.1016/0148-2963(95)00155-7

Sugiyono. (2013). Metode Penelitian Bisnis Kuantitatif, Kualitatif dan R\&D. Bandung: PT. Alfabeta Cipta. 
Trevino, L. K. (1986). Ethical decision making in organizations: A person-situation interactionist model. Academy of management Review, 11(3), 601-617.

Yuliani, N. L. (2011). Determinasi pengambilan keputusan etis auditor internal (studi empiris pada BUMN dan BUMD di Magelang dan Temanggung). Widya Warta: Jurnal Ilmiah Universitas Widya Mandala Madiun, 35(02), 133150 .

Vinayanthi, N. M. ., Wirakusuma, M. G. ., Suprasto, H. B. ., \& Putri, I. G. A. M. A. D. . (2020). The belief on the law of karma moderates the effect of idealism and professional commitment on the ethical decisions of tax consultants. International Research Journal of Management, IT and Social Sciences, 7(6), 175-183. https://doi.org/10.21744/irjmis.v7n6.1035 